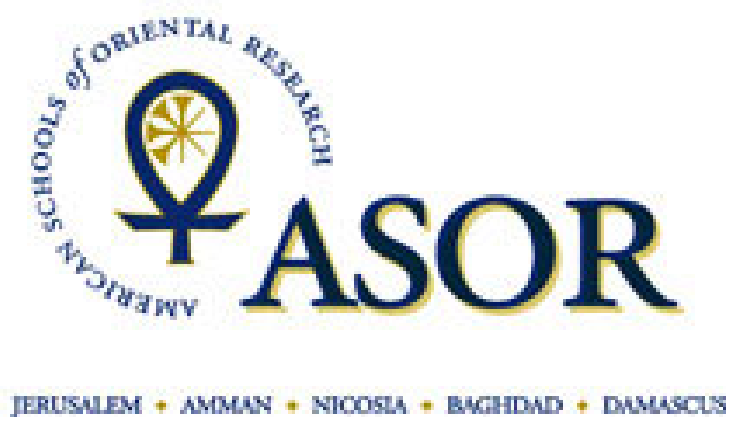

Neo-Assyrian Treaties from the Royal Archives of Nineveh

Author(s): Simo Parpola

Source: Journal of Cuneiform Studies, Vol. 39, No. 2 (Autumn, 1987), pp. 161-189

Published by: The American Schools of Oriental Research

Stable URL: http://www.jstor.org/stable/1359779

Accessed: 06/05/2010 14:30

Your use of the JSTOR archive indicates your acceptance of JSTOR's Terms and Conditions of Use, available at http://www.jstor.org/page/info/about/policies/terms.jsp. JSTOR's Terms and Conditions of Use provides, in part, that unless you have obtained prior permission, you may not download an entire issue of a journal or multiple copies of articles, and you may use content in the JSTOR archive only for your personal, non-commercial use.

Please contact the publisher regarding any further use of this work. Publisher contact information may be obtained at http://www.jstor.org/action/showPublisher?publisherCode=asor.

Each copy of any part of a JSTOR transmission must contain the same copyright notice that appears on the screen or printed page of such transmission.

JSTOR is a not-for-profit service that helps scholars, researchers, and students discover, use, and build upon a wide range of content in a trusted digital archive. We use information technology and tools to increase productivity and facilitate new forms of scholarship. For more information about JSTOR, please contact support@jstor.org. 


\title{
NEO-ASSYRIAN TREATIES FROM THE ROYAL ARCHIVES OF NINEVEH
}

\author{
Simo Parpola \\ University of Helsinki
}

\begin{abstract}
Treaties $(a d \hat{e})^{1}$ played an important and prominent role in Late Assyrian imperial politics. Tying the hands of other big powers with pacts of "friendship and peace" was one of the main goals of Assyrian foreign policy, ${ }^{2}$ as imposing oaths of loyalty on defeated nations was a cornerstone of Assyria's strategy of gradual territorial expansion. ${ }^{3}$ Within the empire's provincial system, pacts of loyalty with the upper class and the Assyrian rank and file served as a means of protecting the king and his heirdesignate against potential conspiracies and uprisings. ${ }^{4}$ The great practical significance of these different treaties to the Assyrian royal house does not need further elaboration, and it can be taken for granted that copies of all important treaty documents were carefully preserved in the imperial archives. ${ }^{5}$
\end{abstract}

1. See the excursus below, pp. 180-83. Abbreviations used in this article are as in CAD, with the following additions: NL = H. W. F. Saggs, "The Nimrud Letters" (Iraq 17 [1955] 21ff., etc., cited by text numbers); VTE $=$ D. J. Wiseman, The Vassal-Treaties of Esarhaddon (London, 1958, cited by lines).

2. A revealing document in this respect is the Midas letter NL 39, re-edited by Postgate, Iraq 35 (1973) 21-34, especially its lines 43-55. On pacts of "friendship and peace" see below, pp. $182 \mathrm{ff}$.

3. From the Middle Assyrian period on, the annexation of new territories to Assyria followed a fixed three-step pattern: (1) political surrender brought about by persuasion, intimidation, or military measures; (2) imposition of a treaty of "eternal vassalage"; (3) total annexation usually complemented by large-scale deportations and harsh military measures. The rigor by which this pattern was observed-step (3) was never taken without step (2)-shows it was a carefully considered strategy essentially built upon step (2), which was pivotal to the process in three respects: First, it harnessed the vassal's economic and military resources to Assyrian imperial use; second, it subjected the defeated nation to a process of gradual and ever-increasing Assyrianization; and third, whenever necessary, it provided a convenient ideological excuse for the extreme measures required by step (3). On the last point compare P. Vargyas, "Le cylindre Rassam et la Bible," Oikumene 3 (1982) 157-62.

4. For a discussion of the function of these treaties on the basis of epistolary evidence see Parpola, Iraq 34 (1972) 30f. The practice of imposing loyalty oaths on Assyrian citizens is only attested from the reign of Sennacherib on; however, since dynastic struggles had become a serious and recurrent problem in Assyrian internal politics long before that reign, earlier treaties of this type may well have existed.

5. Compare for example ABL 90, showing that the tablet contained a treaty with Gurdî (of Tilgarimmu?) was to be returned to the palace after treaty ceremonies in Assur. 
Against this background, it is not surprising that a very considerable part of all extant ancient Near Eastern treaty documents comes from the orbit of the Neo-Assyrian empire. ${ }^{6}$ If anything is surprising, it is the relatively small size of the Neo-Assyrian treaty corpus: the eleven different treaties identified to date only constitute a fraction of the references to various treaties found in contemporary texts (listed in Appendix A), and these in turn can be but a fraction of all treaties once drawn up and filed in the Assyrian archives. ${ }^{7}$ In the present article, intended as a companion piece to Grayson's paper on the same subject elsewhere in this journal, ${ }^{8}$ I am happy to add to the corpus four new texts, all from the Kuyunjik collection of the British Museum. All of these have managed to escape the attention of scholars so far for the simple reason that they are mistakenlydescribed as "letters or reports" in the catalogues of Bezold and King-a fact which gives reason to suspect that even more Assyrian treaty fragments may well be hidden in these catalogues under incorrect labels. ${ }^{9}$ The texts are

6. The list of cuneiform "Staatsverträge etc. und Vereidigungen" in Borger HKl 3 (1975) 41 includes, in addition to the Neo-Assyrian material, about twenty Hittite treaty fragments, six fragments from Alalakh, several fragments from Ugarit, and one possible Middle Assyrian fragment; the only treaty text extant from Egypt is the Hattusili-Ramses treaty edited by K. A. Kitchen, Ramesside Inscriptions 2 (Oxford, 1977) 225ff. On the Aramaic treaties of Sefire see below, p. 183.

7. Note that only four of the extant treaties are actually identifiable in contemporary sources (see Appendix B); hence the available references to treaties must reflect the true number of treaties actually concluded very inadequately. If the total of forty-seven references put together in Appendix $A$ is multiplied by $3.4(=47+14)$, the total number of Assyrian treaties concluded between 745 and 620 B.C. would rise to 160 ; the actual total was probably much higher considering the gaps in our documentation. The relative scantiness of the extant material may indicate that many treaties, especially those concluded with Levantine rulers, were not recorded on clay but on papyrus or leather; note the evidence of treaties on papyrus from the "Papyrus gallery" of Sennacherib's palace in Nineveh discussed by Layard Nineveh and Babylon pp. 155-59. However, the case of the $\mathrm{Ba}^{\circ} \mathrm{al}$ Treaty shows that treaties with Levantine rulers could be written on clay as well, which makes the scarcity of the extant material even more surprising.

8. A. K. Grayson, "Akkadian Treaties of the Seventh Century B.C.," JCS 39 (1987) 127-60. I am grateful to Professor Grayson for making his manuscript available to me before its publication and for providing me with the incentive for this article, which should have been written more than a decade ago.

9. I came across most of the fragments published here as early as 1968 and 1969 when searching through unpublished Kuyunjik tablets for letters to be included in my LAS. The Qedar treaty which I published together with K. Deller in 1968 was also among the fruits of this search; it may be of interest to note that this fragment is described in the Kuyunjik Catalogue (p. 1945) as "part of a report concerning religious affairs." The fragment 83-118,420 (see the next footnote) is similarly described as "part of a religious text including directions for ceremonies and rites" (Catalogue p. 1889). 
published here with the kind permission of the Trustees of the British Museum. ${ }^{10}$

One of the new fragments provides the missing upper left-hand corner of the treaty of Zakutu concerning Assurbanipal, published in 1913 by R. F. Harper in the twelfth volume of his Assyrian and Babylonian Letters as no. 1239. Since the previous edition of ABL 1239 by L. Waterman ${ }^{11}$ leaves much to be desired, the whole text is re-edited here as no. 1 . The other fragments are from previously unknown treaties. Nos. 2 and 3 are domestic loyalty pacts; both are on behalf of Esarhaddon and are atypical in that in both of them the king himself, not his father or some other guardian, appears as the imposer of the treaty. This type of treaty was hitherto known only from a treaty of Sin-šar-iskun certainly postdating his accession $^{12}$ and almost certainly intended to consolidate the new king's shaky position after a bloody civil war; hence it appears likely that at least no. 2 was occasioned by a similar situation and would thus date from about 680 B.C. ${ }^{13}$ No. 4 is part of a multi-column vassal treaty; unfortunately both the date of this interesting text and the identity of the treaty partners remain obscure for lack of onomastic evidence.

While previously published treaties generally fall out of the scope of the present contribution, I could not resist the temptation of appending to the new texts a re-edition of VAT 11449, a small fragment from Assur published in copy by Ebeling in $1948^{14}$ and sketchily edited by him six years later in his Stiftungen und Vorschriften für assyrische Tempel..$^{15}$ As already recognized by Borger some twenty years ago, this text actually is a treaty of Sennacherib, ${ }^{16}$ and a quite important treaty at that. It clearly

10. I wish to thank the whole staff of the Department of Western Asiatic Antiquities, especially the former Keepers, Drs. R. D. Barnett and Edmond Sollberger, for the assistance given to me during the study of the tablets. The join 83-1-18,45+266 (no. 1) was discovered by me in 1974, those included in no. 2 in September 1986. I am much indebted to Ken Uprichard, who after discussing the join $83-1-18,493+\mathrm{Bu} 91-5-9,131$ with me combed through the two subcollections and discovered the fragment $83-1-18,420$, providing the curse section of this text.

11. Royal Correspondence of the Assyrian Empire 2 (1930) 360ff. and 3 (1935) 326f.

12. Ass $13955 \mathrm{z}=$ Weidner, AfO $13(1939-40) 215 \mathrm{n}$. 69 and pl. 14; on the date of the text see Parpola, LAS 2 (1983) p. 4 n. 4.

13. No. 3, which refers to "fumigants" in A 7, may have been occasioned by the unsuccessful coup d'état of 670 B.C.; cf. LAS 2 pp. $238 \mathrm{ff}$. and $278 \mathrm{ff}$.

14. Or NS 17 (1948) pl. 31, reprinted in Ebeling, Parfümrezepte und kultische Texte aus Assur (Rome, 1950).

15. Ebeling Stiftungen no. 2 (p. 9).

16. Borger HKl 1 (1967) 109. 
pertains to the royal succession and, even though the name of the heirdesignate is broken away, there is every reason to believe that the text concerned the promotion of Esarhaddon, hitherto known only from the biased account in Borger Esarh. p. 40f. ${ }^{17}$ What is more, the text contains important evidence for establishing the date of this controversial event. The highly distinctive sequence of gods that appears in the curse sections of the text is otherwise known only from texts relating to Sennacherib's work on the Akitu Chapel of Assur, which is known to have been completed in the king's twenty-second year (683)..$^{18}$ The fact that the Akitu Chapel is actually mentioned in line 8 of the text may indicate that the treaty ceremonies were synchronized with the celebration of the New Year's festival, which would date the text to Nisan 683 or 682 B.C.-a surprisingly late date considering that the promoted prince was already in exile by Nisan $681 !^{19}$

17. I consider it excluded that the text could be a loyalty pact imposed in favor of Esarhaddon's rebel brothers and nullifying an earlier one in favor of Esarhaddon. Not only is there no evidence for the existence of such a treaty, but the very course of events leading to the murder of Sennacherib shows that such a "counter-treaty" was never drawn up (see my remarks in CRRAI 26 [1980] 175). Besides, it can be taken for granted that should a treaty in favor of the defeated (but not eliminated) brothers have existed, Esarhaddon would have been sure to destroy all relevant documents immediately after his accession.

18. See VAT 9656 (=Ebeling Stiftungen no. 1). That this text (dated Sennacherib 22 and sealed with the seal of Assur) was written immediately after the completion of the Akitu Chapel is evident not only from the building history in obv. 5-21 but also from the continuation recording the donation of a large number of people to the Chapel and detailing the of ficials responsible for its administration.

19. See CRRAI 26 (1980) 178 n. 39. 
Text 1. The Zakutu Treaty

BM 83-1-18,45 (ABL 1239) + 83-1-18,266. Photo p. 189.

\section{Transliteration}

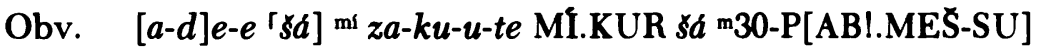
[MA]N KUR aš AMA maš-šur-PAB-AS MAN KUR aš-šur.KI <AMA maš-sur-DÜ-A>

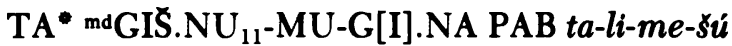

$\mathrm{TA}^{*}{ }^{\mathrm{m} d} \mathrm{GIS} . \mathrm{NU}_{11}-\mathrm{UG}_{5}$.GA-TI.LA ì

5 re-eb-te PAB.MES-š́ TA* NUMUN LUGAL TA*

LÚ.SAG.MEŚ LÚ.NAM.MEŚ LÚ sá ziq-ni

LÚ.SAG.MEŚ LÚ.GUB-IGI TA • LÚ 'zak'-ke-e

$\grave{u}$ LÚ.TU-KUR gab-bu $\emptyset$ ! TA* DUMU.MES KUR $a s ̌ s$ sur

'LÚ' [qd] ]l-lu LÚ dan-'nu!' man-nu sá ina SÀ a-de-e

$10 r^{r} a n-n u '$-te sà miza-ku-u-te MI.KUR ina UGU

[maš-sur-D]Ü-A DUMU SẢ-SÀ-bi-ša HÚL TA• UN.MES KUR gab-bu

[taš-k]un-u-ni man-nu sá a-bu-tú la de-iq-tú

[la t]a-ab-tú ù na-bal-kdt-tu

[ina UG]U maš-šur-DÙ-rA MAN' KUR aš-sur EN-ku-nu

$15[\mathrm{x} \times t] a-s a-{ }^{\top}\left[i^{\top}-a-n i\right.$ te-ep-pa-sáa-a-ni

[nik-l]u! la da-an-qu da-ba-a-bu

[la ta]-' $a^{\top}-b u$ ina UGU maš-sur-DÙ-A MAN KUR as

[EN-ku-nu ina S] SÀ-bi-ku-nu ta-nak-kil-a-nin-ni

[ta-dáb-bu-b]a-a-ni us-su-uk-tú

20 [la de-i]q!-tú mil-ku! (text: lu) la ta-a-bu ša si-bi bar-te

[ina S̆A-bi-ku]-nu! ina UGU maš-sur-DÜ-A MAN KUR aš

EN-ku-nu

[ta-mal-l]ik!-a-ni ta-dáb-bu-ba-a-ni

[TA* $\times$ x x] $\times$ 2-e ina UGU du-a-ki

[šá maš-sur-DÙ-A MAN] KUR aš EN-ku-nu ta-dáb-bu-ba-a-[ni]

25 [aš-šur ${ }^{\mathrm{d}} 30$ dUTU] dSAG.ME.GAR dili-bat

Edge [đUDU.IDIM.SAG].US! d[UDU.IDI]MI.GUD.[UD]

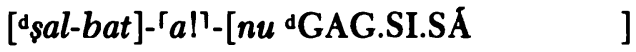

(break of two lines)

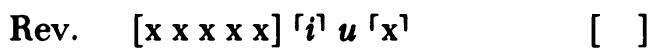

[ù sum-ma] at-tu-nu TA* SA! (text: TA*) UD-me an-ni-r $e^{\top}$ [a-bu-tú la] de-iq-tú sá si-bi bar-te 
[ša ina UGU maš-sur-DÜ-A MAN KUR aš be-li-ku-nu

5 [i-dáb-bu]-bu-u-ni <ta-sam-ma-a-ni> la tal-la-ka-nin-ni [uz-ni] sá mza-ku-u-te AMA-š́ ì sá mas-sur-DÜ-A [MAN KUR as E]N-ku-nu la tu-pat-ta-a-ni ' $\grave{u}^{\top}$ [s] ${ }^{\prime}$ ]m-ma [at-tu]-nu sa da-a-ki ù bul-lu-qi [sá maš-sur]-DÜ-A MAN KUR aš EN-ku-nu ta-sam-ma-a-ni

10 [la ta]l-la-ka-nin-ni uz-ni sá ${ }^{\mathrm{m}} z a-k u-t e ~ 0 !$

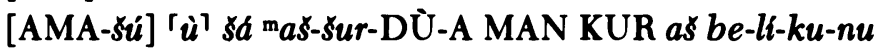
[la tu-pa]t-ta-a-ni ù sum-ma at-tu-nu [ki-i nik-l]u la da-an-qu ina UGU mas-šr-DÜ-A 'MAN KUR as be-li'-ku-nu i-nak-kil-an-ni

15 ta-sam-ma-a-ni la tal-la-ka-nin-ni ina IGI mi za-ku-te AMA-š́ ̀̀ ina IGI mas-šur-DÜ-A MAN KUR as be-li-ku-nu la ta-qab-ba-a-ni ù sum-ma at-tu-nu ta-sam-ma-a-ni tu-da-a-ni mal-a ERIM.MES mu-sam-bi-is-su-u-te

20 mu-sad-bi-bu-u-te <<sa>> ina bir-tuk-ku-nu lu-u ina LÚ sá ziq-ni lu-u ina LÚ.SAG.MES lu-u ina PAB.MES-š́ lu-u ina NUMUN MAN $l u-u$ PAB.MES-ku-nu $l u-u$ EN ta-ba!-te-ku-nu

lu-u ina UN.M[ES K]UR gab-bu ta-sam-ma-a-ni [tu-da-a-ni l] a ta-sab-ba-ta-nin-ni

25 [la ta-du-ka-ni ina $]^{r} \mathrm{UGU}{ }^{\mathrm{m} l} z a-k u-t[e] !$

Edge [AMA-šú ù ina UGU maš-šur-DÜ-A MAN KUR aš] [be-li-ku-nu la tu-ba-l]a-n[in-ni]

\section{Translation}

The covenant of Zakutu, the queen of Senna[cherib, ki]ng of Assyria, mother of Esarhaddon, king of Assyria, <and mother of Assurbanipal, king of Assyria,>

${ }^{3}$ with Samaš-šumu-ukin, his equal brother, with Samašmetu-uballit and the rest of his brothers, with the royal seed, with the magnates and the governors, the bearded and the eunuchs, the royal entourage, with the exempts and all who enter the Palace, with Assyrians high and low:

${ }^{9}$ Anyone who (is included) in this covenant which Queen Zakutu has made with the whole nation concerning her favorite grandson [Assurba]nipal, 
${ }^{12}$ anyone (of you) who should [. . . ] fabricate and carry into effect an ugly and evil thing or a revolt against your lord Assurbanipal, king of Assyria,

${ }^{16}$ in your hearts conceive and put into words an ugly [sch] eme and evil plot against [your lord] Assurbanipal, king of Assyria,

${ }^{19}$ [in yo]ur [hearts] deliberate and formulate an ugly suggestion and evil advice for rebellion and insurrection against your lord Assurbanipal, king of Assyria,

${ }^{23}$ (or) plot [with] another [. . . ] for the murder of your lord [Assurbanipal, king] of Assyria:

${ }^{25}$ [May Ašsur, Sin, Samaš], Jupiter, Venus, Saturn, Mercury, [Mars, and Sirius ... .] (short break)

rev. 2 [Also, you swear that should] you from this day on $<$ hear > an ugly [word] of rebellion and insurrection being spo[ken against] your lord Assurbanipal, king of Assyria, you will come and inform Zakutu his mother and Assurbanipal, [king of Assyria], your lord;

${ }^{7}$ and you swear that should you hear of (a plan) to kill or eliminate your lord [Assur] banipal, king of Assyria, you will come and inform Zakutu [his mother] and your lord Assurbanipal, king of Assyria;

${ }^{12}$ you also swear that should you hear of an ugly [scheme] being elaborated against your lord Assurbanipal, king of Assyria, you will speak out in the presence of Zakutu his mother and your lord, Assurbanipal, king of Assyria;

${ }^{18}$ and you swear that should you hear and know that there are men instigating armed rebellion or fomenting conspiracy in your midst, be they bearded or eunuchs or his brothers or of royal line or your brothers or friends or any one in the entire nation-should you hear and [know] (this), you will seize and [kill] them and bring them to Zakutu [his mother and to Assurbanipal, king of Assyria, your lord.]

\section{Commentary}

The date and historical context of this unique document are not explicitly stated in the text itself but can be easily deduced from its contents. Like VTE, the text is a pact of loyalty to Assurbanipal, but it 
differs from the former in two significant respects: (1) the guardian of the pact is not the king but the queen mother, and (2) its provisions apply to Assurbanipal alone (called king), while Samas-šumu-ukin (not called king) figures among the parties on whom the pact is imposed. These facts fit only one historical situation, the short period of time between Esarhaddon's death (Arabsamna $10=$ November 1, 669 B.C.) and the accession of Assurbanipal the next month. ${ }^{20}$ It can be assumed that the text was drafted soon after the news of Esarhaddon's death had reached Nineveh, and was officially implemented at the coronation ceremony, when all the parties concerned were present, as already proposed by Waterman in his editio princeps. ${ }^{21}$ This scenario perfectly agrees with VTE 83-91 prescribing that in the event of Esarhaddon's untimely death, his sons still being minors, Assurbanipal was to be helped to take the throne of Assyria while Samašsumu-ukin was to be seated on the throne of Babylon. Since Assurbanipal was already married and possibly even had children before his father's death, ${ }^{22}$ it is questionable whether he still was legally a "minor" at the time of his accession. In any case, he certainly needed the support of a senior family member to secure his position in the precarious new situation created by his father's sudden death. ${ }^{23}$

Zakutu's role as the guardian of Assurbanipal is comparable to that of Sammuramat/Semiramis, who for several years guarded the interests of her son Adad-nerari III in line with the common praxis according to which a widow with no grown-up sons would manage her household until her oldest son had become of age. The title "mother" here borne by Zakutu has to be understood accordingly. In the absence of a widowed queenAssurbanipal's real mother had died several years earlier ${ }^{24}$-the queen

20. For the dates see Grayson Chronicles no. 14:29 and 34 (compare 1 iv 31; the exact day of Assurbanipal's accession is not given in the chronicles); for the Julian correlations see my LAS 2, Appendix B.

21. AJSL 29 (1912) lff.

22. See LAS 2 p. 139f. That Assurbanipal was married while crown prince is certain from ABL 308 rev. 5 ff.

23. The situation of course became entirely different once the accession had officially taken place, and there would have been no need for the treaty at a later date. The absolute terminus ante quem of the text is II-668 (the accession of Samaš-sumu-ukin; see obv. 3). I do not understand Wiseman's logic in VTE p. 9, where he considers the beginning of the revolt by Samaš-sumu-ukin (652!) a plausible context for the treaty.

24. On Adar $5=$ February 8, 672 B.C. (Grayson Chronicles p. 85:22). That the dead queen was Assurbanipal's mother can be regarded as certain; see ABL $614=$ LAS 132 and my remarks in LAS 2 pp. 120 and 195. 
mother became the family head and thus, in stepping into the shoes of her daughter-in-law, even the "mother" of her grandson..$^{25}$

Obv. line 2: The words supplied within angle brackets are required by the suffix -sú in line 3, which can only refer to Assurbanipal.

Line 3: The qualification of Samaš-šumu-ukin as Assurbanipal's abu talimu is clearly a reference to VTE 86 , intended to underline that the provisions of VTE were being respected even though the promotion of Samaš-šumu-ukin was temporarily delayed. The much debated term talimu has to be understood in the light of Esarhaddon's domestic policy propagating the notion of a full (albeit cosmetic) equality between Assyria and Babylonia.

Line 4: Contra Streck Asb. p. 249 (followed by Wiseman, VTE p. 7), Samaš-metu-uballit was certainly not the youngest son of Esarhaddon but very probably the third-oldest one. Like Samaš-šumu-ukin and Assurbanipal, but unlike other children of Esarhaddon, he does not have a pompous "royal" name, which indicates that he was born before his father had become king (or even crown prince) and thus very probably had the same mother as his elder brothers. He would thus have been the next in order of succession to the throne, which explains his prominent position in the present treaty. ${ }^{26}$

Line 7: LÚ.SAG.MES = "eunuchs" (not just "officials" or the likel): see the facts put together in my LAS 2 (1983) pp. $20 \mathrm{f}$.

Lines 9-12: This passage looks like an anacoluthon for mannu sa ina libbi adê . . ihattūni, see for example BRM $450 \mathrm{rev.} \mathrm{5'f.,} \mathrm{Grayson} \mathrm{BHLT}$ 106+ ii 8f., VTE 513f., AfO 13 215:1-3. The unique construction in the following lines (mannu sa followed by a predicate in the second person plural) likewise seems an anacoluthon for mannu atta/attunu sa and the like.

Line 11: I take the logogram HÚL here to stand for the adjective hadiu "pleasant, favored," corresponding to meaning 3 of hada v. (CAD H 26f.).

Lines 12-14: Paralleled by VTE 67f. (summa attunu ... epšu bārtu abutu la tābtu la de'iqtu teppašāniššūni). The other provisions of the obverse are not directly paralleled in the Vassal Treaties of Esarhaddon,

25. Note that there is no evidence that ummu "mother" (AHw $31416 \mathrm{f}$.) was ever used in an extended sense to mean "grandmother" (= ummu ummi). On Zakutu/Naqia, see Grayson in the forthcoming second edition of the Cambridge Ancient History, vol. 3/2 ch. 23, and the scattered passages discussed in LAS 2 (see p. 530 sub Naqia).

26. The biographical evidence available on Samaš-metu-uballit and the other children of Esarhaddon is summarized in LAS 2 pp. $116 \mathrm{ff}$. 
perhaps because they are almost identical in content and hence omitted as unnecessary from the longer treaty.

Lines 25f.: Restorations based on VTE 13ff., 414-31, and LAS 13:9ff.; see also LAS 123:7ff. and Iraq 34 22:29. Despite VTE 13ff., the context and space considerations in line 25 imply that the passage is a curse section, not an enumeration of gods witnessing the treaty.

Rev. lines 2-5 // 7-12: Compare summa attunu abutu (la tābtu) la de'iqtu la bañtu (ša epēs sarrūti) ša ina mubhi Aššrur-bāni-apli . . la la tābatūni . . . la taqabbāni, VTE 72-82 // 108-122. The restoration [i-dábbu]-bu-ni in rev. 5 is based on obv. 20-22; for $\langle t a-s a m-m a-a-n i>$, see rev. 9, 15 , and the VTE passages just cited.

On the subjunctive summa clauses in this passage see the note on Text $2: 4^{\prime}$.

Rev. lines 18-27: Compare VTE 130-46. After rev. 27 the edge is uninscribed and the curse section normally closing Assyrian treaties is definitely missing.

Text 2. Esarhaddon's Accession Treaty

BM 83-1-18,420 + 83-1-18,493 (CT 53 937) + Bu 91-5-9,131. Copy p. 187.

Transliteration

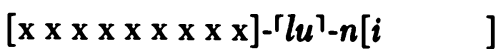

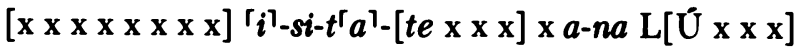

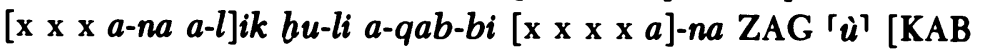
$a$-šap-par]

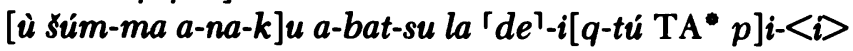

NUMUN-šu a-šam-m[u-u-ni]

$5^{\prime} \quad$ [ú-la-a šúm-ma] TA• pi-i sá 1-en T[A SA L]Ú.GAL.MES

[LÚ.NAM.MES]

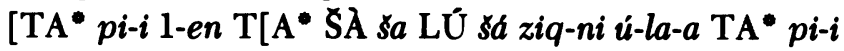
[LÚ.SAG.MES]

[a-šam-mu-u-ni] ù $a-n a$ maš-surur-PAB (text: AS)-[SUM]-na EN-iá la $a-q a b-b[u-u-n i]$

[šrim-ma la ARAD-šú] a-na-ku-u-ni ù [de-i]q-tú-šú la $a-z a k-k[a r-u-n i]$

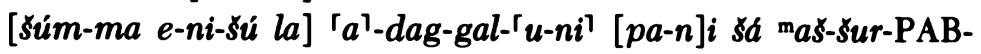
SUM-na E[N-iá]

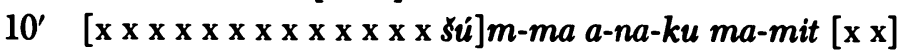

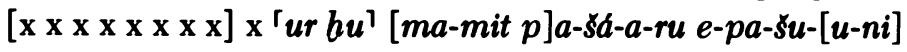




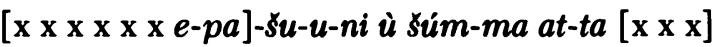

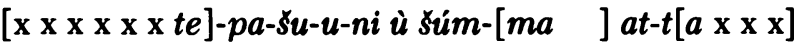

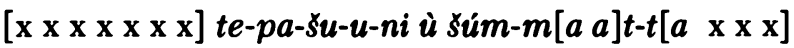

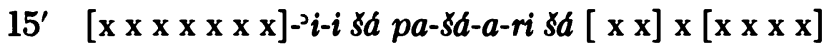

[AN.S̊̊R AD DINGIR.MES LUGAL $k$ ] $i s-s a t$ AN-e $u$ KI.TIM se-ret-s[u kab-tú li-mid-su]

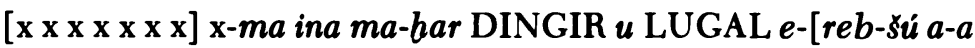
iq-bi]

[ ${ }^{\mathrm{N} I N . L I L}$ AMA DINGIR.MES $\left.h i\right]$-ir-tu na-ram-ta-[su $\mathrm{x} \times \mathrm{x}$ ]

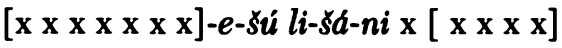

20 ' 15 dbe-let $\mathrm{MURUB}_{4} u$ ME ina $t$ ]a-ba-zi dan-ni [GIS.BAN-š́ lis-bir]

[ina sá-pal LÚ.KÚR-š́ l]i-se-ši-ib-š́ ka-mi-iš [ Ø?]

[¿UTU x x x x x GI]S zi-ba-ni-tum la kit-ti [ $\left.\begin{array}{lll} & \times & \text { x }\end{array}\right]$

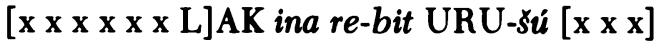

[`NIN.GAL? x x x x x x]-bi ina ma-har `30 [ $\left.\begin{array}{lll}x & \mathbf{x} & \mathrm{x}\end{array}\right]$

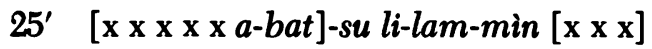

['U.GUR dan-dan-nu/qar-rad DINGIR.MES ina] sib-ti u

NAM.ÚS.MES [ $x$ x $x$ x]

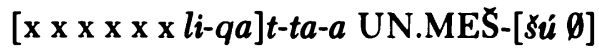

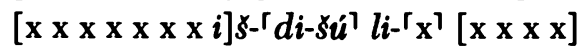

Rest broken away

\section{Translation}

(Beginning destroyed)

${ }^{1}[\ldots . . . \mathrm{t}]$ ower[s . . . ] I will tell [ . . ] to [ . . and] trav[ellers, $I$ will send messengers] to the south and [the north . . .].

${ }^{4}$ I swear that should I he[ar an ug]ly word about him [from the mou]th of his seed, [should I hear it] from the mouth of one of the magnates or [governors], [from the mouth of one] of the bearded or from the mouth of [the eunuchs], I will go and tell it to Esarhaddon, my lord,

${ }^{8}$ [I swear] that I [will] be [his servant] and (only) speak good of him, that I [will be] loyal to him and [. . . the fa]ce of Esarhaddon my lord, [...]

${ }^{10}$ I swear that I will [keep] the oath [of this treaty tablet] and not perform the (rite of) undoing the [oath . . .] or make [. . ].

${ }^{12}$ You (sic!) also swear that you will not make [. . .], and that you will not make [. . . ] and will not [. . .] of undoing [. . ]. $<$ He who 
sins against the wording of this treaty tablet: $>$

${ }^{16}$ [May Aššur, father of the gods and king] of the totality of Heaven and Earth [impose a heavy] punishment [upon him ... and forbid his ent]ering into the presence of God and King!

${ }^{18}$ May [Mullissu, mother of the gods, his] beloved wife [...] change his [. . .]!

${ }^{20}$ [May Ištar, lady of warfare break his bow in] a fierce battle, [bind his arms] and surrender him as captive [to his enemy]!

${ }^{22}$ [May Samaš . . .] an untrue balance [. . .] in the plaza of his city!

${ }^{24}[$ May Nikkal . . .] worsen his case [. . . ] in the presence of Sin [her husband]!

${ }^{26}$ [May Nerigal, the strongest among the gods] destroy [his] people through plague and pestilence [. . .]!

(Rest destroyed)

\section{Commentary}

The inscribed surface of this tablet is entirely flat and nothing is left of the edges. It is therefore impossible to tell whether it was originally a single- or a multi-column tablet; the original column width and the number of signs missing on each line can, however, be determined with reasonable accuracy through a careful consideration of the available restorations. The inscribed side is almost certainly the reverse, despite its flatness. The other side is completely destroyed.

Line $3^{\prime}$ : $\quad[a-l] i k$ bu-li: taken as the Neo-Assyrian equivalent of alik harrāni "traveler" (CAD A/1 342f.). This line seems to imply that the party on whom the treaty was imposed was obliged to spread the news of Esarhaddon's victory/sovereignty actively, both to incoming travellers and outsiders; hence it supports the dating of the document after the civil war of 681. No comparable provisions are to be found in other NeoAssyrian treaties. See also the note on line $8^{\prime}$ below.

$a-q a b-b i$ : sic, not $a-q a b-b[u-u-n i]$ (subj.). Note that non-subjunctive verbal forms, not preceded by summa and indicating prohibitions or positive promises also occur in Text 4 (ii 3, 4; iii 3,5, 16) side by side with subjunctive forms preceded by summa (iii 4). This would seem to support the position of $\mathbf{K}$. Watanabe, who takes the subjunctive summa clause in treaties to indicate irreal conditional sentences, with the nuance of "in the unthinkable event that ..." or "if, heaven forbid, ..." (oral communication, September 1986; contrast GAG $\$ 185 \mathrm{~h})$. Note, however, that contrary to the implications of this theory, the subjunctive summa clause in 
Text 4 iii 4 is inserted between non-subjunctive verbal forms without a following apodosis, and that an apodosis is also missing after a string of subjunctive summa clauses in Text 1 and VTE (lines $397 \mathrm{ff}$.), and regularly in assertory oaths (see the passages listed in LAS 2 p. 17 ad 9ff.). The translations in the present paper therefore follow GAG \$185. The seemingly irregular use of the subjunctive in Text 1 (rev. 9, 15; see also 2:4 and VTE 80 and 119) is a case of concord resulting from the embedding of a non-modal summa clause within an assertory one ("summa summa . . . tašammea la taqabbāni $\rightarrow$ šmma . . tašammāni la taqabbāni).

Lines 4'ff.: See VTE 318-27 (especially 326, a-bat-su la DÜG.GA-tu la SIG $_{5}-t u$ ); for the restorations compare VTE 73-82.

Line 8': See the examples of damiqta zakāru "to speak good (of somebody)" cited CAD D 64f. and Z 21. Note the implication of the passage: the party on whom the treaty was imposed was actively to speak good of Esarhaddon-to counteract the "evil gossip, slander, and lies" spread about him while he was crown prince (Borger Esarh. 41 i 26)? Exact parallels are not found in other Assyrian treaties; compare VTE 318-27.

Line 9': Instead of [pa-n]i one could also consider restoring [uz-n]i; compare Zakutu Treaty rev. 10 and elsewhere.

Line 10'f.: māmìt pašăru is otherwise known as an exorcistic ritual used for curing diseases attributed to curses (see LAS 2 p. 148 ad 160 rev. $5^{\prime}$ ). The present passage, paralleled by VTE 373-85, suggests that it was also (frequently?) used as a practical means to evade curses resulting from broken oaths.

Lines 12' f.: Note the change from first to second person and later (in the curse section) to third person singular forms, indicating that the text was meant for oral presentation, lines $1^{\prime}-11^{\prime}$ to be said by the party on whom the treaty was imposed, the rest by the imposing party. A similar alternation between first and second person forms also occurs in Text 4 below; compare also the first person plural forms in VTE 494-512 and ABL 1105. The reason for the switch to third person singular forms in the curse section remains uncertain. It may be noted, however, that in VTE the equivalent of lines $10^{\prime} \mathrm{ff}$. is followed by the formula sa mämit tuppi adê egga ... (VTE 397f.), which introduces a curse section with third person singular object suffixes in BRM $450 \mathrm{rev}$. $5 \mathrm{ff}$. But can a similar formula be restored in line $15^{\prime}$ ?

Line 16': For the beginning compare TCL 4314, VTE 25, AfO $817 \mathrm{rev}$. v 5, Borger Esarh p. 46:30, 53:1, etc.; there is no room for EN KUR.KUR in the break. For the end of the line see the parallels listed in CAD K 26a; this curse was hitherto not attested in Assyrian treaties. 
Line 17': Compare VTE 420 (there referring to Sin).

Line 18': Compare VTE 417 ('NIN.LIL bi-ir-tu na-ram-ta-su). The epithet AMA DINGIR.MES required by the break is attested for Mullissu, for example in Streck Asb p. 210:5.

Line 19': Possibly [...tè]-e-š́u (for tēnšu) lišanni "may confuse his mind"; see the parallels cited in AHw 3 1167a sub sanu IV G 10, and note tèl-š́u-[nu], ABL 1287:10', and dēnsuu >de-e-sú, ADD 330 rev. 4 and 460 rev. 5.

Lines $20^{\prime} f .:$ The same curse is also found in VTE 453f. and $\mathrm{Ba}^{\mathrm{c}}$ al Treaty iv 18 (Borger Esarh. p. 109).

Line 22': Compare Reiner Surpu II 42 and VIII 67; the restoration of the curse remains problematic.

Text 3. Oath of Loyalty to Esarhaddon

Bu 91-5-9,22. Photo p. 188.

Side A Beginning broken away

$\left\ulcorner\boldsymbol{l} \boldsymbol{u}^{\top}[\right.$

$a-n a$ UR[U

]

$a-n a{ }^{\mathrm{m}} a s ̌-s u r-\mathrm{P}[\mathrm{AB}-\mathrm{AS}$ ]

sum-ma LÚ [

$5^{\prime} \quad i z-z a-z u-u-n[i \quad]$

NUMUN-šú $u$ U[N.MEŠ-šu ]

la tu-sal-l[a?- ]

$i q-q u-u-k u[n-u-n i]$

$q u-t a-a-r[i]$

$10^{\prime}$ la tu-sal-x[ ]

LUGAL KUR aš-sur [ ]

$r_{\mathbf{X} x} \mathbf{x}^{\top}$ ]

Rest broken away

Side B Beginning broken away

(Beginning destroyed)

.. [ . . ]

to the cit[y ...]

to Esarh[addon ... .]

you swear that $[\ldots]$

standing [ . . . ]

his seed and his fa[mily ... .]

you will resc[ue ... .]

has sacrificed yo[u ... .]

fumigant[s ...]

you will resc[ue ...]

king of Assyria [. . .]

(Lacuna)

$i$-[ ]

la [ ]

sum-m[a]

sá at $t[u-n u$ ]

$5^{\prime}$ ina $g u-m[u r-t i]$

an [ ]

Rest broken away

not [...]

you s[wear that ... .]

what you [...]

whol[eheartedly ... .]

(Rest destroyed) 


\section{Commentary}

A line 3': The reading of the second element of the royal name as $\mathrm{PA}[\mathrm{B}]$ not $\mathrm{D}[\mathrm{U}$ is certain.

Line 7': The last sign actually looks like $\mathrm{PA}[\mathrm{B}]$ rather than $\mathrm{L}[\mathrm{A}]$.

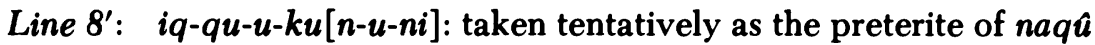
"to libate, sacrifice" (with 2nd pl. object suffix), in the absence of a better solution. It should be noted, however, that the verb is otherwise not attested in the suggested usage and that the spelling of the pronominal suffix with kun is unusual though not unparalleled (compare nap-sat-kun VTE 651 and $i$-qab-ba-kan-u-ni VTE 336 and 340).

Line 9': On the use of fumigants (qutāru) in the treatment of Esarhaddon's disease, see LAS 2 pp. 250, 255, and 265. The occurrence of the word here may indicate that this treaty dates from 670 B.C., since the unsuccessful coup d'etat of $\mathbf{6 7 0}$ coincided with a worsening of the king's condition (see LAS 2 p. 238f. and above, p. 163 and n. 13.).

$B$ line 5': Compare VTE 310.

\section{Text 4. Treaty with a Vassal King}

K.4439. Photo p. 188.

\section{Transliteration}

Obv. i entirely destroyed

ii beginning broken away

$\left[\begin{array}{llllllll} & \mathbf{x} & \mathbf{x} & \mathrm{x} & \mathbf{x} & \mathrm{x}\end{array}\right]^{\mathrm{r}} \mathrm{x}^{\top}$

$\left[\begin{array}{lllll}\mathrm{x} & \mathrm{x} & \mathrm{x} & \mathrm{x} & \mathrm{x}\end{array}\right]-k a-s^{-s u}$

[is-si]-sú ${ }^{\top} l a^{\top} t a-{ }^{\top}{ }^{\top} a^{\top}-l i m$

[pi-i i] s-si-š́u 'la' ta-šá-kan

$5^{\prime} \quad[t a]-p a-l[d b-a n]-n i$

[SI] $\mathrm{G}_{5}-i a$ te- ${ }^{\top} p a^{\top}-d s^{-}-{ }^{\top} m a^{\top}$

[šm-ma] ${ }^{\top} \mathrm{SIG}_{5}-i a^{\top}$ te-ta-pa-ás

[x $\times$ x $\times$ x $\quad x-r] u-b u g a b-b u$

$\left[\begin{array}{lllllllll}\mathbf{x} & \mathrm{x} & \mathbf{x} & \mathrm{x} & \mathrm{x} & \mathrm{x} & \mathrm{x}\end{array}\right]-b u$

$10^{\prime} \quad\left[\begin{array}{llllllll} & \mathbf{x} & \mathrm{x} & \mathrm{x} & \mathrm{x} & \mathrm{x} & \mathrm{x}\end{array}\right]-d i-u$

[šum-ma a-na-ku ina U]GU-bi-ka

$\left[\begin{array}{lllllllll}\mathbf{x} & \mathbf{x} & \mathrm{x} & \mathrm{x} & \mathrm{x} & \mathrm{x} & a\end{array}\right]$ l-lak

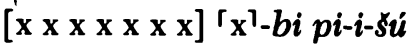

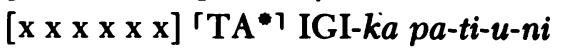

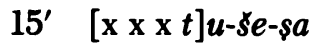

$\left[\begin{array}{lll}\mathrm{x} & \mathrm{x} & \boldsymbol{s}\end{array}\right] a k-n a-s u-u-n i$ 
[x x lu-s]am-ri-su

[x x] 1-' en ina' SÀ ARAD.MES-ka

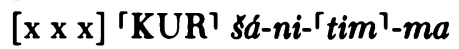

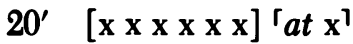

Rev. iii lu-u ina SU.2 $\mathrm{KU}_{6}$ sá tam- ${ }^{-}$tim $^{\urcorner}$

lu-u ina SU.2 MUSEN sá AN-e

la ta-sap-par

sum-ma at-ta ta-qab-bu-u-ni

5 [ma]-「a'a-lik a-na LUGAL am-mi-e qi-bi

[ma-a] an-nu-rig LUGAL KUR as-sur

[ina UG]U-bi-ka il-la-ka

[nik]-lu me-me-ni us-se-UNUG

[ina UGU]-bi-ka a-na e-pa-si

10 [ù] a-bu-tú am-mar ta-sam-mu-ni

[lu-u T]A pi-i 1-en LUGAL.MES

[lu-u T]A pa-an 1-et KUR.MES

[sa ina UG]U-hi-ni ina UGU KUR ass-sur

[qur]-bu-u-ni la ta-bu-u-ni

15 [TA] IGI-ia la tu-pa-zar

[a-na] ' $a^{\top}-a-s i$ ta-sap-pa-ra

[tu-s]a-ás-man-ni

[dib-bi] am-mar sáa-na-ku

[is-si-ka a-d]a-bu-ub-u-ni

20 [x $\times 1 \times$ x x-p]i am-mar sá a-me-lu-ti

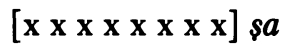

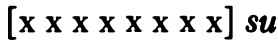

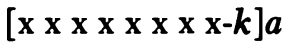

rest (at least 15 lines) broken away

iv entirely destroyed

\section{Translation}

Col. i (Totally destroyed)

Col. ii (Beginning destroyed)

[.. .] him.

You will not make peace [with] him

nor make [common cause] with him,

5 but will fe[ar] me

and do what is [good] to me.

[If] you do what is good to me, 
all [...]

(Break of two lines)

[Should] I march

[. . . ] against you

[. . .] his mouth

[. . .] keeping at a distance from you

15 [. . . ] you will bring forth

[. . .] is set to him

[. . . let them] make difficult

[. . .] one of your servants

$[\ldots]$ another country

20 [...]...

Col. iii 3 You will send no [messages],

1 neither with a fish of the sea

2 nor with a bird of the sky.

4 You swear that you will not say:

5 "Go and tell to that king:

6 'Now, the king of Assyria

7 is marching against you,

8 he has . . .ed a certain [strat]agem

9 to use against you."'

15 [Nor] will you conceal from me

10 anything that you hear,

11 be it from the mouth of a king

12 or on account of a country,

14 (anything) that bears upon or is harmful

13 to us or Assyria,

16 but you will write to me

17 and bring it to my attention.

18 Whatever [matters]

19 I may discu[ss with you],

20 whatever [.. .] the mankind (Rest broken away)

Col. iv Completely destroyed)

\section{Commentary}

Traces of a vertical dividing line to the left of column iii show that this tablet was originally inscribed with more than one column of text; judging 
from the curvature of the surviving fragment, only one column on both sides seems to be lost. The serial order of the sides has been determined from the contents; compare especially ii $1 l^{\prime} f$. with iii $6 f$.

ii 4': For the restoration see for example Iraq 34 22:18.

$i i i 8^{\prime}$ : If the word preceding $g a b-b u$ is a geographical name, the likeliest restoration would be [KUR $a-r$ ] $u$-bu "Arabia," which would imply that the text is a treaty with an Arab king (see Appendix A, nos. 2, 31, 32, 37, and 38).

iii lf.: The reference to "fish of the sea" makes it clear that this passage is to be understood as a hyperbole forbidding any imaginable method of sending secret messages; the passage also shows that the idea of messagecarrying birds in this context was quite familiar to the writer. It therefore seems possible that carrier pigeons were already used for military communication in Sargonid Assyria, as they were later in the Roman empire. The earliest certain references to birds-pigeons-used for carrying messages date from Roman/Early Islamic times; see Frederick E. Zeuner, Geschichte der Haustiere (Munich, 1967) p. 385, and D. Müller, Der Islam 32 (1957) 163.

iii 8: The obscure last sign looks like

iii 11f.: 1-en LUGAL.MES, 1-et KUR.MES: compare Old Aramaic hd mlkn "a(ny) king" (R. Degen, Altaramäische Grammatik •72, attested in Barrakab and Sefire). It remains unclear whether this construction is an Aramaism in Neo-Assyrian or vice versa, since it is relatively well attested in Neo-Assyrian (see 1-en LÚ.NAGAR.MES "a carpenter," ABL 87 rev. 7; 1-en URU.SE.MES-ia "a village of mine," ABL 1003:13; 1-en URU.MEŠ-ia "a town of mine," ABL 1070:10.

\section{Text 5. The Akitu Treaty}

VAT 11449. Copy Ebeling Parfümrez. pl. 31 (not collated)

\section{Transliteration}

Obv.? beginning destroyed

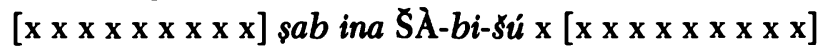

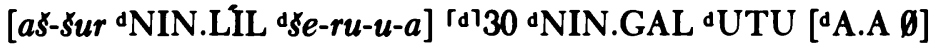
[ ${ }^{\triangleleft} a-n u m$ an-tum ${ }^{\mathrm{d}} \mathrm{E}$ ]N.LIL ${ }^{\mathrm{dIM}} \mathrm{d} s a-l a$ ['GAM-KUR ${ }^{\mathrm{d}} 15$ ša AN-e]

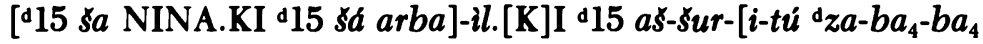
'BA.Ú]

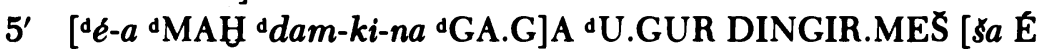
d-ki-it(?)]

[x $\times$ x ar-rat la nap-šur ma-ru-u]s!l-tu li-[ru-ru-ku-nu] 


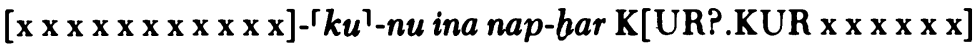

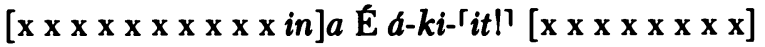

(edge)

Rev.? (lacuna?)

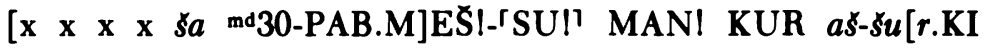
EN-ku-nu]

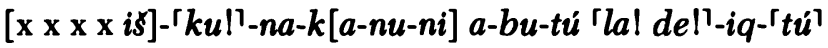
[ta-sam-ma-a-ni]

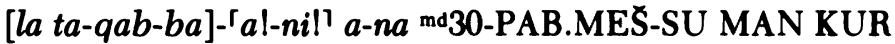
ass-sur.[KI EN-ku-nu]

[la ta-lak-a-ni-ni S]Å-「ba!'-ku-nu a-na LUGAL EN-ku-nu 'la! ga!'-mur-[u-ni $\emptyset]$

$5^{\prime} \quad$ [šum-ma ${ }^{\mathrm{m} a} a s-s u r-\mathrm{PAB}-\mathrm{AS}$ DUMU-MAN GAL sa É-US- $\left.t i \grave{u}\right]^{\mathrm{r}} r e-$ $e b^{\top}-t i$ DUMU.MES LUGAL [ $s a$ md30-PAB.MES-SU]

[MAN KUR aš-sur.KI ú-kal-lim]-rúl'-ka-nu-ni la ta-na-sar-sá$n[u !-n i \emptyset]$

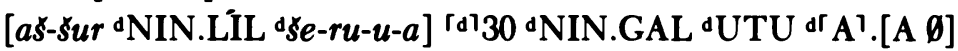

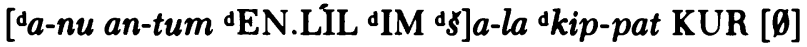

[d $15 s a$ AN-e ${ }^{d} 15 s a$ URU.NINA.KI] d $15 s a$ URU [arba-il.KI]

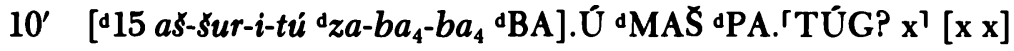

[DINGIR.MES sá É á-ki-it $\times$ x x ar]-rat la nap-sur ma-r[u-uštu]

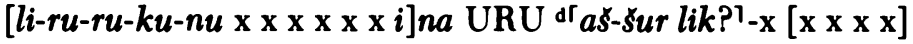
rest broken away

\section{Translation}

(Beginning destroyed)

${ }^{1}[\ldots]$ in his heart [ . . ],

${ }^{2}$ may [Ǎšur, Mullissu, Serua], Sin, Nikkal, Samaš, [Nur, Anu, Antu, I]llil, Adad, Sala, [Kippat-mati, Ištar of Heaven, Ištar of Nineveh, Ištar of Arb]ela, Assyrian Ištar, [Zababa, Babu, Ea, Belet-ili, Kakk]a, and Nerigal, the gods [of the Akitu Chapel. . . ] curse you with an indissoluble, griev] ous [curse, may they . . . ] your [ . . ] in all $l[$ ands ... .] the Akitu Chapel [. . .]

(Break)

rev.? 1 [You swear that you will . . which Sennach]erib, king of Assyr[ia, your lord], has set to you;

${ }^{2}$ you swear that [should you hear] improper things, you will [speak up, going] to Sennacherib, king of Assyria, [your lord], and totally devoting yourselves to the king, your lord; 
${ }^{5}$ you swear that you will protect [Esarhaddon, the crown prince of the Succession Palace, and] the other princes [whom. Sennacherib, king of Assyria has indica]ted to you. $<$ Whoever sins against the wording of this treaty, $>$

${ }^{7}$ [may Aššur, Mullissu, Serua], Sin, Nikkal, Samaš, $N u[r$, Anu, Antu, Illil, Adad, Š]ala, Kippat-mati, [Ištar of Heaven, Ištar of Nineveh], Ištar of [Arbela, Assyrian Ištar, Zababa, Ba]bu, Inurta, Nusku, and [. . ., the gods of the Akitu Chapel . . . curse you with] an indissoluble, grievous curse [. . ] in the city of Aššur [...]

(Rest destroyed)

\section{Commentary}

Obv. (?) lines 2'-5' and rev. lines 7'-10': Restored from BM 121206 (= van Driel, Cult of Aššur pp. 80ff.) rev. ix 27'-34'; see also BM $121206 \mathrm{v}$ $13^{\prime}-16^{\prime}$ and VAT 13596 (Or. NS 22 27ff.) i 5-15 (summarized as "[the gods of] the Akitu Chapel at the left and right of Aššr)," and Luckenbill OIP 2 142:11-15 (enumerating gods going to the Akitu Chapel before and behind Aššur). As can be seen from these passages, lists of "Akitu gods" could vary slightly depending on circumstances; however, it is important to note that they all relate to the Akitu reform of Sennacherib and that the particular sequence(s) found here are not attested in any other contexts.

The reading of "A.A as Nür "(personified) light" is based on the alphabetic spelling $\mathrm{Nr}$ in the Sefire Treaty (H. Donner and W. Röllig, Kanaanäische und aramäische Inschriften no. 222 A 9).

Rev.(?) line 2'-4': restored from VTE 148-52; see also VTE 73-82 and 108-122, and Zakutu Treaty (no. 1 above) rev. 3-7. For the phrase libbu ana $X$ gammuru (alternating with libbu issi $X$ gammuru), see ADD 646:13 // 647:13 (ana, both Neo-Assyrian), and ABL 846 rev. 20 // 917 rev. 15 (ana/itti, both Neo-Babylonian).

Lines 5'-6': Compare VTE 92-100, 62-65, 494-97, and 513-17; Zakutu Treaty (no. 1 above) 5; and Borger Esarh. p. 40 i $18 f$.

\section{EXCURSUS: ON THE TERM ADE, "TREATY, COVENANT"}

All extant Neo-Assyrian treaties (both domestic and international) are defined as adê in the texts themselves. Apparently, largely because adê is a loanword from Aramaic, many scholars believe that the term actually did not mean "treaty" in general, but referred to a specific type of treaty ("adê 
agreement," "adê type of treaty," "loyalty oath") imported relatively late to Assyria from the "West." I find myself unable to share this view for a number of reasons.

First of all, loyalty oath or vassal treaty as an institution was by no means a late "Western" innovation in Assyria but had been part and parcel of all Mesopotamian imperial systems since the earliest times, starting with Ebla and the Old Akkadian empire. ${ }^{27}$ Typically Neo-Assyrian practices are already well attested in the Middle Assyrian period, as can be seen in the Tiglath-pileser I passage AKA 69 v 14ff. (= Grayson ARI 2 p. 13): "I made them (=the kings of Nairi) swear by my great gods an oath of eternal vassaldom (mämìt ilijja rabûti ana ardutti uttammišunu), took their sons as hostages, imposed upon them a [heavy] tribute and returned them to their lands."

Secondly, it must be kept in mind that in Neo-Assyrian usage adê by no means refers only to "oaths of loyalty imposed by a superior party upon an inferior party," but can also denote:

(1) solemn promises made by God to King, involving no oaths or imposition on either party (see Craig ABRT $122 \mathrm{f}$. ii 1-32);

(2) a sworn agreement between gods (Craig ABRT 23 ii 33-24 i 14; note also Eretz Israel 5 154:19');

(3) a peace treaty between two great kings (see ABL $328: 15$ and CT 54 $580: 6$, where adê refers to the Esarhaddon-Urtaku treaty described as tū $\overline{b u}$ u sulummâ "good will and peace" in Borger Esarh. p. 59 v 31 and as tābtu (u) ibrütu "friendship and comradeship" in Streck Asb. p. 104 iv 16. This treaty is also alluded to in ABL 918:9ff., a letter from Esarhaddon to Urtaku, which shows that it was sealed by oaths sworn by Assyrian and Elamite gods and by an exchange of children between the two kings ${ }^{28}$ );

(4) an agreement between a great king and lesser kings sought by the latter (see Streck Asb. 12 i 123f. referring to Delta kinglets bound in vassalage to Assyria: "They sent their messengers to Tarqû, king of Kush, to establish a mutual treaty of reconciliation" (šakān adê u satìme); note, incidentally, how closely the formulation of this passage parallels that of the Esarhaddon passage referred to under (3)!);

(5) conspiracy (see [a]-de-e sa si-i-bi "treaty of rebellion," ABL 1091:4', referring to the conspiracy leading to Sennacherib's murder; note also VTE 147ff.: "You swear that you will not make common cause with the

27. See Sollberger, Studi Eblaiti 3 (1980) 129ff., and the treaty of Naram-Sin with Elam edited by Hinz, ZA 58 (1967) 66ff.

28. See Parpola, Iraq 34 (1972) 34 n. 66. 
perpetrators of insurrection, ... you will not make a treaty $(a-d e-e)$ by serving food at table and drinking from a cup, ... but you will go and report to Assurbanipal . . . and seize and put to death the instigators of rebellion." Note that the meal ceremony sealing this "treaty of rebellion" also plays a prominent part in the divine covenant referred to above, under (2)).

Clearly, the word adê covers a much broader semantic field than just "loyalty oath" and is best taken as a general term for any solemn, binding agreement. "Covenant" would probably be the closest equivalent in English, but "treaty," "pact," and even "loyalty oath" are equally acceptable, depending on the context. Regarding the latter, it must be kept in mind, though, that adê, as such, does not mean "oath" or even "sworn agreement"; the proper expression for that concept was the hendiadys ade (u) $m \bar{a} m \bar{i} t u / t a ̄ m i \bar{t} u .{ }^{29}$

The relationship of adê to other terms for "treaty" occurring in NeoAssyrian sources ${ }^{30}$ appears in full clarity from the references to the Esarhaddon-Urtaku treaty cited above under (3): adê was the proper Neo-Assyrian term for "treaty," "covenant"; the other terms (mainly attested in royal inscriptions) are either broad synonyms of adê or poetic/literary descriptions of the substance of actual pacts. In this context it should be noted that the same terminology was used for treaties regardless of whether the concluding parties were of equal or inferior status, although the actual provisions (terms in another sense) of such treaties would of course be quite different. Both types of treaty could be referred to as "peace treaties," and the verb salāmu "to make peace" could equally well connote "to seek detente" as "to surrender" (for the former, see LUGAL KUR NIM.MA.KI $u$ LUGAL KUR $a s-s[u r . K I]$ ( . . .) ina a-mat ¿AMAR.UTU it-ti a-ba-meš is-se-el-mu u a-na EN.MES a-de-eša-ba-meš it-tu-ra "the king of Elam and the king of Assyria by the command of Marduk made peace with one another and became treaty partners," CT 54 580:3-7; for the latter see a-de-e is-se-e-ni sul-uk!-nu ma-a ni-si-lim, ABL 129 rev. $19 \mathrm{f}$.; note also salmüti "peacemakers" referring to tribute-bringing vassal kings in the Ishtar prophecy (Langdon Tammuz pl. 3 iii 18). Thus the circumstance that all extant treaty documents happen to be concluded with an "inferior party" must not be misunderstood to imply that only such treaties were called adé; that we have no extant specimens of other types of treaties defined as adê is just a coincidence. 
That Middle Assyrian riksu/rikiltu "treaty" was replaced by an Aramaic word in Neo-Assyrian is an interesting phenomenon to be considered within the general framework of Assyro-Aramaic ethnolinguistic contact. But just how far can one go in drawing conclusions from it? Can the Neo-Assyrian replacements of Middle Assyrian words for "battle," "quiver," or "ram" by Aramaic qarābu, saltu, $j \bar{a} b i l u$ be taken to reflect a "Westernization" of Assyria's fighting methods, quiver makes, and breeds of rams? It is possible, but unlikely. A perfectly natural explanation for the intrusion of adê into Neo-Assyrian can be found in Assyria's expansion in the tenth through eighth centuries, which must have involved innumerable treaties imposed on Aramean city states that would naturally have been mostly drawn up in Aramaic. It is not hard to imagine that as a result of this repetitive process adê as a colloquial term for "treaty" gradually gained foothold in Assyrian administrative parlance and then rapidly in NeoAssyrian at large. By contrast, it is difficult to see why the Assyrians, with their long-standing and well-tested imperial traditions and ideology, would have bothered to take over the administrative practices of their conquered adversaries.

I believe that the alleged Aramaic treaty tradition largely is a myth. What evidence do we have for it? The Sefire Treaty, which is the only extant specimen of this "tradition," is in reality nothing but an Assyrian treaty imposed on a defeated adversary, but written in his mother tongue. In some details of its formulation, this treaty may well conform with local traditions, but it is good to keep in mind that these local traditions also had their roots in older practices largely originating in Mesopotamia. 
APPENDIX A

REFERENCES TO TREATIES IN 8TH/7TH CENTURY ASSYRIAN SOURCES

\section{International Treaties}

King Treaty Partner Reference

(1) Tigl. Tutamû of Unqi

(2) " Samsi of Arabia

(3) " Mitinti of Ashkelon

(4) " Zaqiru of Bit-Sa'alli

(5) Sar. Ilu-bi'di of Hamath

(6) " Kiakki of Sinubtu

(7) " Pisiri of Carchemish

(8) " Urzanâ of Muşaşir

(9) " Tarbunazi of Melidi

(10) " Merodach-baladan

(11) " Muttallu of Commagene

(12) " Ursâ I of Urartu

(13) " Gurdî (of Tilgarimmu?)

(14) " (elders? of) Sealand

(15) " city of Kuluman

(16) " Zabgagaeans

(17) " a city in Ellipi

(18) Senn. Padî of Ekron

(19) Esarh. Nabu-zer-kitti-lešir

(20) " Abdi-Milkutti of Sidon

(21) " Samaš-ibni of Bit-Dakuri

(22) " Urtaku of Elam

(23) " Mugallu of Melidi

(24) " Bartatua of Iškuza

(25) " Hut(!)-Tesub of Subria

(26) " Ursâ II of Urartu

(27) " Babylonian officials
Rost Tigl. III p. 16:92

Rost Tigl. III 36:210

Rost Tigl. III 38:235

Rost Tigl. III 58:19

Lie Sar. 19, Winckler 102:33

Lie Sar. 68, Winckler 102:28

Lie Sar. 73 and parallels

Lie Sar. 149, TCL 3310

Lie Sar. 208, Winckler no. 69:7

Lie Sar. 264, Winckler 112:79

LieSar. 462, Winckler 116:112f.

TCL 392 and 148

ABL 90

ABL 1029:11

ABL $129: 8$

ABL 129 rev. 19

ABL 1008 rev. 4

OIP 2 31:74

Borger Esarh. p. 46:41

Borger Esarh. 48:66

Borger Esarh. 52:64

Borger Esarh. 59:33, cf. ABL 328:15 and 918:9ff.

Knudtzon Gebete 54:2f.

PRT 16:6ff. and rev. 7

Borger Esarh. p. 102 i 1, ii 23

Borger Esarh. 106 iii 32

Parpola LAS 284:19ff. 


King Treaty Partner Reference

(28) Asb. Egyptian kinglets

Streck Asb. p. 12 i 118

(29) " Necho etc.

Streck Asb. 14 ii 9, 160:33

(30) " Nabu-bel-šumate of Sealand

Streck Asb. 60 vii 18

(31) " Uwaite' b. Bir-Dada

Streck Asb. 64 v 85

(32) " Abiyate' of Qedar

Streck Asb. 68:45 etc., ABL $350(!)$

(33) " Indabigaš of Elam

Bauer Asb. p. 91:2'f.

(34) " Urtaku of Elam

Streck Asb. p. 104 iv 16

(35) " šandabakku of Nippur

Streck Asb. 108 iv 59

(36) " Ummanigaš of Elam

Streck Asb. 126 vi 96

(37) " Yauta’ b. Haza-Il

Streck Asb. 132 vii $91 \mathrm{ff}$.

(38) " Natnu of Nabatea

Streck Asb. 144 ix 41 lff.

(39) " Babylonians

ABL 202

(40) " a Babylonian

ABL 539 rev. $15 f$.

(41) " Mušezib-Marduk etc.

ABL 280:25ff.

(42) " Simbur

ABL 1380:5

(43) " [Nabu-ušabši] of Uruk

ABL 998 rev. 10

See also ABL 1341:6 and 1404:19

\section{Domestic Treaties}

Reference

(44) Senn. promotion of Esarhaddon

Borger Esarh. p. 40:19, 43:50, and 44:80

(45) Esarh. promotion of Assurbanipal Streck Asb. p. 4:21f., ABL 301 rev., and Samaš-šumu-ukin 11, 831 rev. 2ff., 1110:19ff.; LAS 133 rev. 18f. 211:12

(46) Zakutu accession of Assurbanipal Streck Asb. p. 30 iii $96 \mathrm{f}$.

(47) - accession of Ašur-etel-ilani Postgate Royal Grants no. 14:11 See also ABL 231, 472, and 555:7 
APPENDIX B. EXTANT NEO-ASSYRIAN TREATIES

1. International

\begin{tabular}{llcl} 
Assyrian King & Treaty Partner & Date & Publication \\
\hline (1) Samši-Adad V & Marduk-zakir-šumi & c. 822 & AfO 828 \\
(2) Ašur-nerari V & Mati-ilu of Arpad & c. 754 & AfO 8 25f. \\
(2a) " & " & c. 754 & Iraq 32 pl. 36 \\
(3) Esarhaddon & Bacal of Tyre & c. 677 & Borger Esarh. pl. 3f. \\
(4) Assurbanipal & [Abiyate'] of Qedar & c. 652 & Or NS 37 464f. \\
(5) " & Urukians(?) " & 652 & ABL 1105 \\
(6) ? & ? & $?$ & here no. 4
\end{tabular}

2. Domestic

King/Ruler Purpose/Occasion Date Publication

(7) Sennacherib promotion of Esarhaddon 683 Ebeling Parfümrez.

pl. 3

(8) Esarhaddon accession of Esarhaddon $681^{?}$ here no. 2

(9) " promotion of Assurbanipal 672 VTE and Samaš-šumu-ukin

(9a) $\quad "$
$(10) \quad 1$

(11) rebellion? 670 here no. 3

(12) Zakutu accession of Assurbanipal 669 ABL 1239

(13) Sin-šum-lešir accession of Aššur-etel-ilani 677? BRM 450

(14) Sin-sar-iłkun end of civil war 625? AfO 13 pl. 14

NB: Note that only five of these treaties (nos. 4, 7, 9, 12, and 13) are explicitly referred to in contemporary sources (see Appendix A nos. 32 and 44-46). In addition, the existence of (3) is implied but not made explicit by Borger Esarh. p. 49 iii 16 and 112:13. 


\section{3-1-18,420 + 83-1-18,483 + Bu 91-5-9,131}

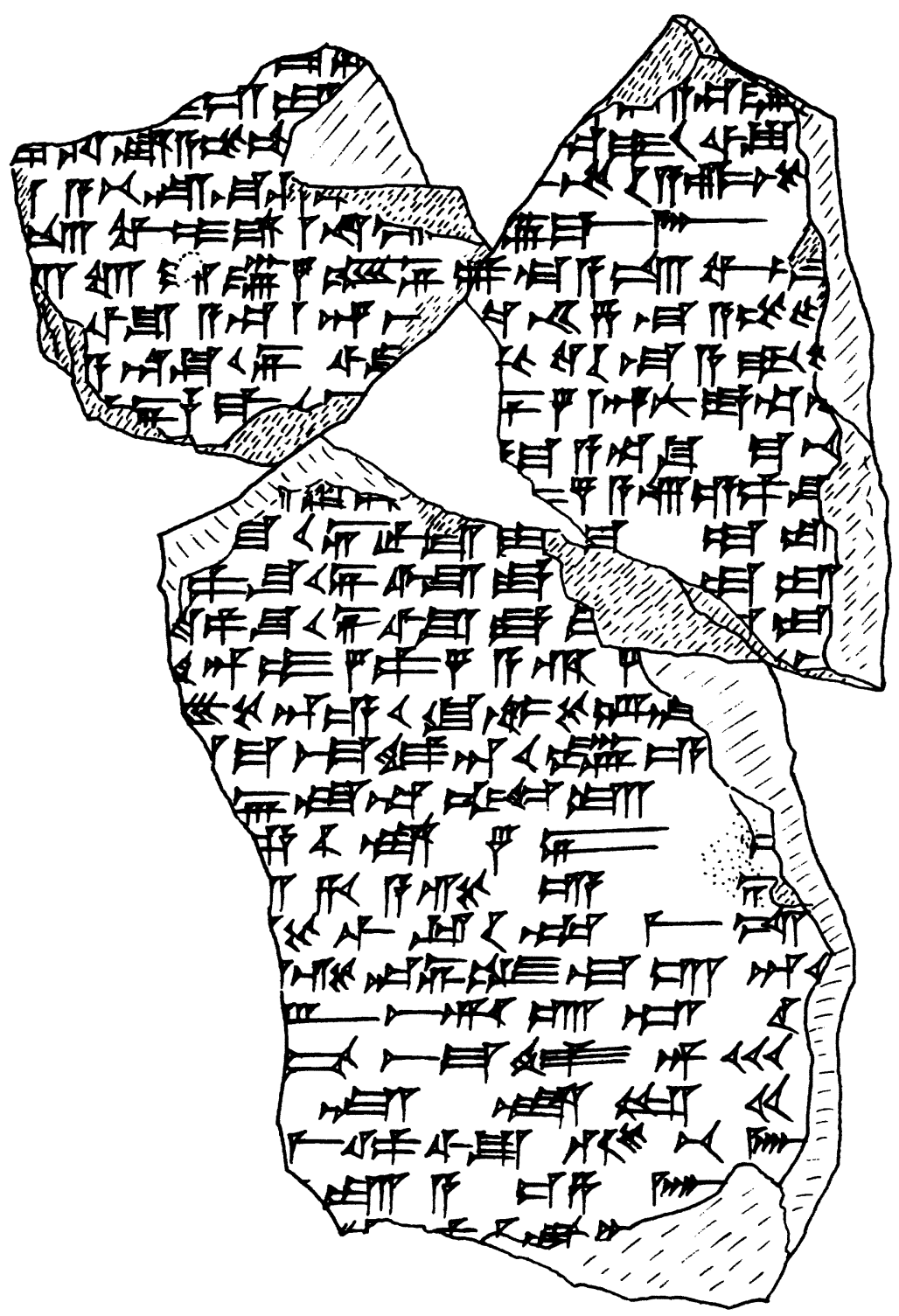



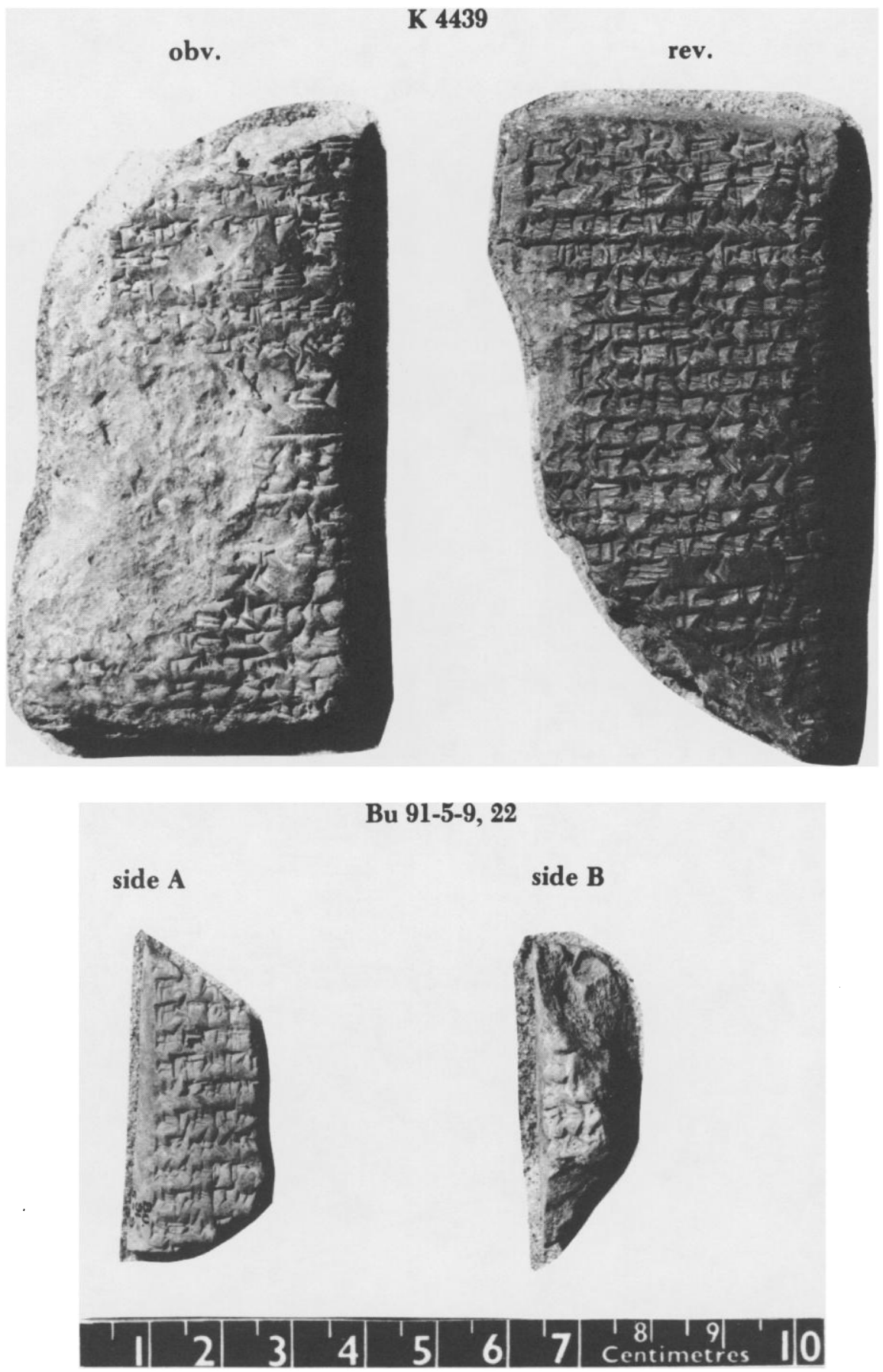

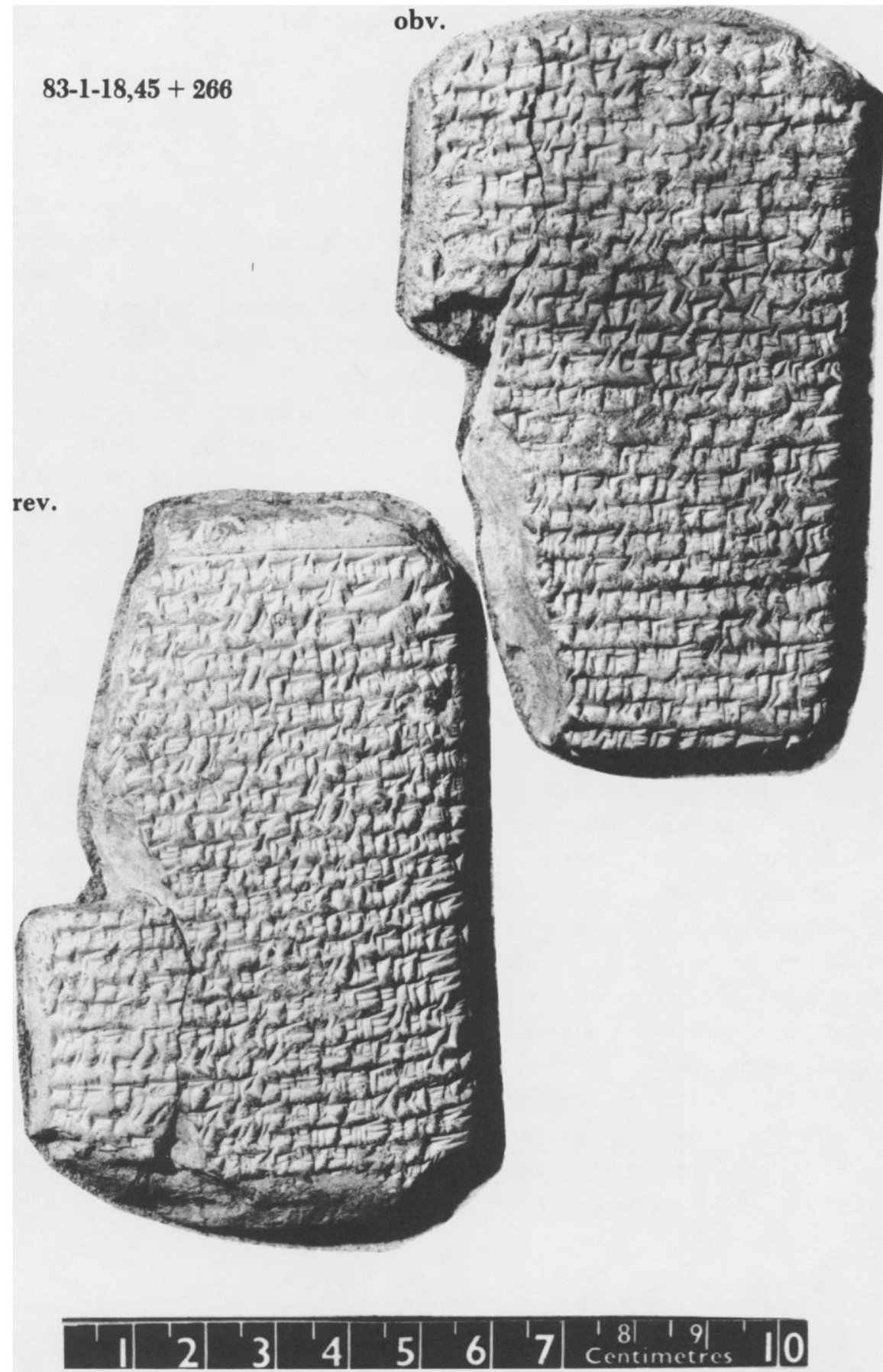